\title{
The ruling layer in the teachings of G. Mosca, V. Pareto and classics of Eurasianism: comparative legal analysis
}

El estrato dominante en las enseñanzas de G. Mosca, V. Pareto y los clásicos del eurasianismo: análisis jurídico comparativo

\begin{abstract}
The purpose of this paper is to compare the concepts of ruling selection and the leading layer in the works of G. Mosca, V. Pareto and the teachings of the Eurasians. In the course of their work, the authors find common and special features in these ideas and try to predict possible ways of applying the Eurasian doctrine to the Russian political reality. The authors ask about the preconditions for the formation of an original Eurasian view of the elite and the relevance of this concept in modern Russia. In the final part, the authors come to intermediate conclusions of the scientific research, which can serve as a basis for further study of the topic. The work can be useful for legal theorists, elitologists, politicians, as well as those who are interested in the Eurasian doctrine.
\end{abstract}

Keywords: Elite, lead layer, ruling selection, political elite, elitology, eurasianism.

\section{RESUMEN}

El propósito de este artículo es comparar los conceptos de selección dominante y la capa principal en los trabajos de G. Mosca, V. Pareto y las enseñanzas de los euroasiáticos. En el curso de su trabajo, los autores encuentran características comunes y especiales en estas ideas e intentan predecir posibles formas de aplicar la doctrina euroasiática a la realidad política rusa. Los autores preguntan sobre las condiciones previas para la formación de una visión euroasiática original de la élite y la relevancia de este concepto en la Rusia moderna. En la parte final, los autores llegan a conclusiones intermedias de la investigación científica, que pueden servir como base para un mayor estudio del tema. El trabajo puede ser útil para teóricos legales, elitólogos, políticos, así como para aquellos que estén interesados en la doctrina euroasiática.

Palabras clave: Elite, capa de plomo, selección gobernante, elite política, elitología, eurasianismo. 


\section{INTRODUCTION}

The development of modern Russian society depends to a decisive degree on the ability of the country's elite to consolidate society and mobilize all strata of the population to achieve socially significant goals. These processes testify to the change in the role of the elite as the governing layer of society. Such an approach to understanding the elite has been established in the conservative legal thought of Russia, where the elite was identified, first of all, with the authority, God's choice, ideological inspiration of the people.

The growing contradictions in the field of national economy, socio-political sphere, spiritual and cultural life gives rise to a number of questions about the correlation between the interests of political elites and the diverse interests and needs of society, about the measure of social orientation of the modern political elite, thus actualizing the interest in the problem of studying the Russian elite.

Undoubtedly, turning to foreign mechanisms of reproduction of elite, it is necessary to pay attention and to domestic vision of the given question, including, addressing to a heritage of a historical-legal, political-legal science. In the conditions of revival of the Eurasian ideas and creation of the new Eurasian space, that part of conservative legal ideology of Russia, which is connected, with the doctrine of Eurasians acquires the special urgency. Undoubtedly, the attention to the Eurasian political and legal doctrine is now focused not only on the part of Russian science, but also abroad, because the creation of the Eurasian economic space, which is justified to some extent by the ideas of the concept studied by the authors, has a significant impact on the global economy and politics (Sergi, 2018).

Dividing the elite into the leading layer and the ruling selection, ideologists, classics of Eurasianism in detail concern the functioning of these components, their purpose, role and nature of interaction (Vasiliev, 2016).

The authors of this paper hypothesize that traditionalist legal values still prevail in the Russian legal consciousness, which have a direct impact on the preservation of a conservative approach to the definition of the concept of the elite, and thus the social order and legal system in modern Russia.

To test this hypothesis, researchers carry out a comparative analysis of the definition of the concept of elite, data by G. Mosca and B. Pareto, as well as the Eurasians, and then turn to the historical experience of defining the elite and studying the current understanding of the issue by Russian citizens. Such a systematic, consistent study of the proposed topic is conducted for the first time and allows us to assume that the authors of the paper believe that Eurasian ideologists have formulated a special vision of the theory of the elites, based on the historical experience of Russia, as well as the mentality of Russian (at the time - Russian) society.

Theoretical bases of research. Conceptual design of elite science took place at the end of the XX century in the works of Italian sociologists V. Pareto and G. Mosca. The main directions of elite theory were developed by G. Lassuell, C. Mannheim, R. Mills, I. Schumpeter and others. The theoretical basis for the studies of Russian elites has been expanded by the works of G.K. Ashin, M.N. Afanasiev and other authors. Stratification studies of post-Soviet ruling elites were conducted by O.V. Kryshtanovskaya and V.V. Radayev, A.B. Dooka, O.V. Gaman-Golutvina, V.G. Ignatov, N.Y. Lapina, A.M. Starostin, A.E. Chirikova are devoted to studying the political activity of elites at the regional level. As an empirical basis of the author's work, he used sociological and statistical data from the platforms Colta.ru, "Kommersant", "Medusa", as well as data from his own sociological research.

Practical and scientific significance. The scientific significance is conditioned by the absence of studies of the Russian elite as a historical and legal category. In the present work, the concept and types of elite are considered through the prism of the mentality of the people, conservative thinking and attitude to power structures. The originality of the work lies in the atypical formulation of the author's question about the concept of the elite, the promotion of his own interesting hypothesis.

\section{Methods}

The work uses a civilizational scientific approach, which is followed by the Eurasians themselves. With this approach, the national (or ethnic) identity always bears the imprint of civilization itself, because it is carried out within the framework of civilizational (conscious or unconscious) identification.

At the first stage of our work, we analyzed the achievements of foreign science concerning the theory of the elite. The theoretical basis of this stage of research was the works of V. Pareto and G. Mosca, classics of foreign elite. Using methods of analysis, synthesis, induction and deduction, it was possible to determine the fundamental positions of the concepts of these scientists, as well as to formulate the main similarities and differences in their views.

The fundamental question of the second stage of this study was the ratio of the concept of the elite in the foreign concepts of G. Mosca (1939) and B. Pareto (1935) with its Eurasian interpretation. The authors were interested in such aspects of the topic as functional and substantial characteristics of the leading layer and the ruling selection. The research was based on the works of N. Alekseev (2000), N. Trubetsky (2000) and P. Savitsky (1997). By the method of analysis, synthesis and comparison of the above-mentioned authors, the concepts of the leading layer and ruling selection, criteria of differentiation of these terms and their functions were determined. Applying the historical and comparative method, we explained why the Eurasian understanding of the ruling selection and the leading layer is different from the developments of classical elitism.

The third stage is an empirical study conducted through a Survio-based questionnaire. 144 Russian citizens aged 18 to 60 participated in the survey. Respondents had to answer five questions concerning the understanding of the elite in modern society. When answering the first question, it was necessary to choose the most accurate notion of elite, 
according to the respondents. Definitions given to the elite by foreign scholars - founders of elite theory, modern Russian scholars, as well as Eurasians - were used as answer options. In the second question, it was suggested to choose the features that characterize the elite. In the third question, the participants were asked to choose a drawing that most fully reflects the concept of "elite". In addition, participants were asked to choose from among the leading public figures of citizens, who could be called the elite. Since this article is a peculiar result of the research, the authors also publish the results of the survey in part in order to make the material more concise and concise.

\section{DEVELOPMENT}

\section{Results}

The results can be summarized as follows.

1. Views of G. Mosca (1939) and V. Pareto (1968) is based on the elitist worldview, which took place in ancient philosophy and was most fully formulated by Plato (2019), who strongly opposed the admission of demos (people) to the management of the state, called it a "crowd", hostile wisdom, associated virtue, courage and intelligence as the highest dignity of people with belonging to the aristocracy, knowing how to manage the state.

In addition, it is possible to find sketches of the theory of elite at Confucius, Machiavelli, Carleil, and Nietzsche. According to Machiavelli, who replaced ethics with a value-based knowledge of the power structure, representatives of the ruling class are divided into "lions" who have a sense of loyalty to the state, are conservative, are not afraid to use force, and into "foxes" - sly, cunning, unscrupulous reformers, i.e. they should be both strong and cunning (Machiavelli, 2004).

1.1 In theory B. Pareto people are always governed by elites, except for a short period. In his understanding, the history of humankind is a history of replacing certain elites with other elites.

After reading Pareto's theory, it is possible to determine that the elite are those who have received the highest index in their field of activity, who have reached the highest level of competence ("Treatise on general sociology").

. Pareto singled out "the highest classes" or aristocracy, which are understood as "people who occupy a high position according to the degree of their influence and political and social power" (in the etymological meaning of the word: aristos - the best). At the same time, most members of the elite in this concept have a certain set of qualities - whether good or bad - that provide power.

Besides, he divides the "upper layer" itself into subgroups, pointing to the heterogeneity of the elite: the ruling elite, the non-controlling elite, the political elite. At the same time, a specific layer of people cannot define the elite, or the upper class, or the aristocracy (Pareto used these terms interchangeably), because the social classes are not homogeneous.

Naming the story "the cemetery of aristocracy", he deduced the law of circulation of the elite, according to which the old elite captures a new and vice versa, and this struggle is the cyclicality, circulation, renewal of the elite. According to R. P. Marco, the law of circulation of V. Pareto's elites has a more profound meaning than simply the transfer of power from group to group - its basis is the redistribution of wealth (P'erez-Marco, 2014).

Repeat with N. Machiavelli, he divided the elite into "foxes" and "lions," the first of which hold power through diplomatic intrigue and cunning, and the second with force (Machiavelli, 2004). At the same time, Pareto drew attention to the positive aspects of such governance, pointing out that the elites, especially the ruling class, are well aware of the unequal distribution of materials and intangible assets in society and their interests. At the same time, the elite acts more logically than illogically, thus remaining afloat.

1.2 Based on the ideas of G. Mosca, it is possible to define the elite as the most politically active people, oriented to the power, organized minority, managing the unorganized majority.

G. Mosca argued that in any type of society at any point in history, there are two classes of people - the class that rules and the class that is ruled (1939), and in this sense was repeated by W. Pareto (1935). The first class of society consists of a few and is endowed with all political power and privileges, while the other class is composed of a large number of people and is subordinate to the first class.

In the elite, there is always a leader, and this is not necessarily the one who is endowed with power through the law or the one who is known to everyone. However, under certain conditions, the entire power is concentrated in the hands of this person.

The ruling class or the head of state must be concerned about the thoughts and feelings of the masses in order to get their support; otherwise, they will not be able to rule.

According to G. Mosca, the historically ruling class is trying to justify its existence by using some universal moral principles, superiority, etc. According to G. Mosca, at a certain stage of historical development, the ruling classes are no longer able to justify their power solely by actual ownership of it, so they need to look for another justification - the moral and legal basis, or "political formula", which should support the beliefs and moods of society or its overwhelming part. 
G. Mosca, like C. Pareto singled out two types of elite - the ruling class and the second layer. Since the ruling class cannot lead and direct society sufficiently, the second layer performs an auxiliary function in this matter. At the same time, the members of the ruling class should be recruited almost entirely from the representatives of the society itself, the overwhelming class.

Despite the fact that the views of G. Mosca and B. Pareto differed significantly from each other, they show a common "Machiavellian" spirit - the elite is equated to power, the entire historical path of the state is the struggle of the elites and the opposition of different elites ("coming", "going away") to each other in the distribution of power and economic benefits.

2. Undoubtedly, the conclusions of the Eurasians go back to Plato's philosophical ideas, "for whom the question of conscious organization of the ruling selection in the state was the most basic and important political issue. In addition, Plato noted that the problem rests on the organization of the leading stratum or "ruling selection", which would not allow the authorities to break away from the people.

Turning to the understanding of the Eurasians of the leading stratum and the ruling selection as a way to organize the elite in the Eurasian society, we can note the following fundamental theses.

2.1 The leading layer is recognized as a natural necessity of any state. Indeed, it is inconceivable that the very existence of the state machine without the asset that drives it, as well as the impossibility of progress (any - political, economic, spiritual, etc.). Moreover, in the environment of this stratum, one can always clearly identify a certain state (governmental) asset, i.e. the ruling elite. It should be noted that the very idea of singling out two stages of the elite - the leading stratum and the ruling selection - is in a sense a repetition of the ideas of Italian thinkers.

In a general view, the leading layer performs the following functions: "Moral, not violent" leadership (the analogy with G. Mosca, who singled out such leadership in the case of exhaustion of all other motivations, and in the history of Russia at the time of the emergence of the Eurasian ideology, as it seems to us, they are exhausted), the embodiment and adherence to the state idea (ideocracy, Eydos according to Plato - "the thoughts of God"), a gradual self-renewal: a sharp change of composition leads to inevitable collapse, an example - The socialist revolution in Russia. It should be noted that in this case, ideologists do not mention the change of elites by means of struggle or cunning, we are talking more about the renewal of the natural (according to the Eurasians - even the "natural", as well as the tree gradually grows with new leaves). Undoubtedly, observing the experience of bloody transformations of the Russian state on the way to socialism, the Eurasians could not allow any other solution to this issue.

2.2 At the same time, a group of government activists with power (in the theory of N.N. Alekseev (2000) - the "ruling selection") ideally performs a political function, represents the people on the basis of the "old" principle rather than the class principle (an exclusively Eurasian thesis), and ensures the enforcement of law under the threat of coercion.

Thus, the categories of the leading stratum and the ruling selection are not identical, just as the elite itself is not identified by the Eurasians with the aristocracy. Note: the Eurasians have never used such phrases as "ruling class", "leading class", even in passing. We have listed the functions of each stratum of the elite above, and their principal difference is that the ruling stratum is formed from the stratum of the leader, who is the "pillar of the state" not only on the basis of political power or morality, but also represents the cultural, (ideological, economic and other) color of the nation. The leading layer is formed on the basis of the worldview, personal contribution to the life of the state, replenishing with new forces, which seems to us to be an original vision of the methods of selection of the elite, although somewhat utopian. The Eurasians denied the possibility of its merger with the apparatus of state coercion, because in this case, the leading selection can inevitably turn into a kind of bureaucracy, "devoid of creative ideals".

2.3 It is impossible to determine exactly what is the key criterion for dividing the leading stratum from the rest of the population of the state. N.N. Alekseev saw this criterion in the "moral leadership", but did not explain what exactly to mean by it. N.S. Trubetskoy (2000) rightly pointed out that there is a precise relationship between the type of selection, on the one hand, and the form of government, on the other, which is seen as the influence of the theory of the elites of G. Mosca and B. Pareto.

N.S. Trubetskoy singled out three main types of selection of the ruling stratum: aristocratic (military-aristocratic, bureaucratic-aristocratic, and oligarchic), democratic (plutocratic-democratic, ochlococratic) and ideocratic, and the ideocratic type of selection was thought to be futuristic in many ways. Thus, in the aristocratic selection of the ruling stratum is selected because of the nobility of origin, and the political system in this selection is expressed in absolute monarchy or despotism. The scientist contrasted the democratic and aristocratic type of elite selection with the ideocratic type developed by the Eurasians, which intersects with Schmitt's philosophy. We believe that the Eurasians have gone a little further in this matter, but a significant issue is the procedure of selection of citizens to the elite only based on their support for the idea ("the idea of the ruler", "eidos") of the state.

P.N. Savitsky noted: "The leading layer is the first reality that they see in the state life. In any state order, it is possible to distinguish the domination of a certain group of people united by one or another feature... Elements of this kind are available in any state order: they can be found in the aristocracy, in gerontocracy, and even in plutocracy" (Savitsky, 1997). 
Examples of the leading stratum N.N. Alekseev (2000) at different stages of Russia's development are the princely squad, the service class of Moscow rulers, the nobility of the imperial period, the Communist Party.

2.4 It seems to the special authors that the position noted by N.N. Alekseev is that the leading stratum, united not by the class principle but by the principle of service (the ideal of the Eurasians), can be in power only when it acts "under the banner of ideas and ideals that will be consistent with the spirit of a given historical epoch".

Discussing the ideocratic type of the state, M. Bassin, S. Glebov and M. Laruel (Bassin et al, 2015) believe that the "idea-governor" is understood by the Eurasians as the main link between the ruling layer and society. It seems that the moods of the Eurasians in this regard are somewhat romantic and arrogant, but they themselves refer to historical examples of how the Russian state has managed to embody, if not the state of ideocratic character, then at least some of its features concerning the relations between the authorities and the people. Therefore, in the study of the elite in Eurasia, it is not superfluous to turn to the historical preconditions for the formation of such a concept, such an understanding of the phenomenon.

Speaking about the criteria for the selection of the elite in Russia, it can be noted that in ancient Russia the criteria for elitism were physical strength, courage, ability to possess weapons, high position and respect in their environment. In Kyivan Rus' and other princedoms, the important criterion of an elitism also was considered an origin and nobility of the sort guaranteeing to the person, which possesses them, a place in elite.

In the XII-XV centuries. - The national elite was differentiated into the main group of boyars and a minor group of so-called "boyar children". To take part in law-making processes could only full boyars. In addition, the transition from "boyar children" to full-fledged boyars was possible only when the boyars' offspring achieved an appropriate level of experience and professional and business qualities.

One of the most important criteria taken into account in the formation of the elite in the policy of Ivan IV, who sought to replace the traditional boyars' elite, in the loyalty of which he had doubts, was considered personal devotion of subordinates to the top manager. In fact, the Tsar laid the foundations for the use of the political search for the formation of the elite. The selection of oprichniki was carried out by a special commission, which included A. D. Basmanov, A. I. Vyazemsky and P. Zaitsev, who carefully studied the pedigrees of the candidates in order to exclude persons who had direct connections with the aristocratic environment.

Since the middle of the 16th century, such a form of elitist representation as cathedrals has been manifested. In the XVII century. Zemstvo councils solved the most important political and legal issues and by virtue of the nature of the councils took into account all the major countervailing factors. The best representatives of all classes were present at the cathedrals. When making decisions, the Council was guided by the interests of the entire population and tried to reflect this in law-making activities.

With the advent of Peter the Great, the principles of formation and the role of the social elite have changed dramatically. All this was replaced by a new elite, which was formed according to its own individual achievements in public service, which was identified with the service to the emperor in the first place, and then to the state as the property of the Tsar.

The criteria of elitism in the Russian Empire underwent significant changes after the fall of the tsarist regime and the establishment of Soviet power in October 1917. A significant part of the former political, law enforcement and religious elite was destroyed during the revolution and repressions. Starting from this period up to December 1991, membership in the Communist Party of the Soviet State became an integral criterion of social elitism and a condition for participation in law-making processes.

The authors will not be original if they note that although the definition of the concept of the elite is historically variable, and the criteria for its selection correlate with the "spirit of the era", the latter are still "cumulative" in nature. In other words, with the emergence of new approaches to the definition of the elite in Russia, the previous approaches do not disappear for the moment, and for some time "experience" themselves and are used as auxiliary, although not necessarily publicly available.

Since the idea of the Eurasians is a special way of Russia as a Eurasian state, we can say that the theory of the ruling selection and the leading layer of Eurasians is an adaptation of the views of G. Mosca and B. Pareto under the Russian reality that is proved by historical preconditions of formation of elite in Russia. The authors do not undertake to assert that the Eurasian ideologists did it purposefully, as the concept of elite appears in the Russian language a little later, but intuitively, spontaneously such understanding has developed, including, thanks to the civilizational approach. And this is not only and not so much about the "special way of Russia", Slavophilism (according to some scientists, the source of Eurasianism) and conservatism, but rather about a sober view of what is available at hand - historical experience, geographical location, diversity of ethnicities and cultures, mentality and mentality.

At the third stage of the research we asked ourselves what the elite is understood by the modern Russians, because it is necessary to note that the understanding of the elite is historically variable and corresponds to one or another trend, political situation, level of economic development, etc. One could not ignore the fact that M. Laruelle (Laruelle, 2015) considers the doctrine of the Eurasians forgotten, far from being understood by modern citizens 
and used exclusively to justify the foreign policy pursued by the Russian government today. The authors note that they have found the origins of the Eurasian concept with modern ways of selecting the elite, and tried to find out which of the interpretations of the elite is closer to modern Russians and how much the Eurasians were able to predict, feel what they themselves call the "spirit" of the Russian people.

Surprisingly, but the most popular definition of the elite was the Eurasian one. It is noteworthy that the surveyed citizens chose from a variety of proposed definitions of the elite those in which power, political influence and power were taken as determinants (the authors of these definitions are D. G. Kozlov). Mosca, V. Pareto, A. Toynbee, M. Weber and others.

Despite the fact that such a vision is more in line with Western concepts of elites, this phenomenon is easily explained by the fact that in the Russian legal consciousness there is a stereotype that "he who is above the position is right", which is remotely reminiscent of the structural interpretation of the elite. If we look at the variants lower in terms of popularity, then the second place is occupied by the definitions of domestic scientists, who use the ideocratic criterion of the elite (the embodiment of a national idea, its compliance with it, the impact on social processes), and the third place is occupied by the value criterion, which indicates the need for members of the elite to have the appropriate moral attitudes and values.

In the second question of the questionnaire, we were asked to choose from a list of criteria by which respondents would identify a person belonging to the elite. The most popular answers were "high level of intellectual development" (39.1\%), "Representation of the people, solving socially significant problems through state resources" (46.4\%), "Management skills" (29\%). Meanwhile, analyzing the results of the answer to the question "Which of the following citizens would you rank among the elite", we noticed that subconsciously more attention is paid to moral and moral attitudes and management skills, and a high level of intellectual development is evaluated only in conjunction with other characteristics.

It should be noted that as criteria of "elite" we have given all the variants of interpretation of the elite throughout the history of Russia, as well as the signs put forward by the Eurasians and Italian elite. Respondents still actively associate with the elite the nobility of the family; individual achievements in service ("to serve a place for themselves"), decency, but the physical strength, entrepreneurial abilities, direct stay in power are relegated to the background. This distinguishes the domestic understanding of the elite, its conscious image, from the Western concepts, where the criteria for the elite are a combination of professional and business qualities, hard work, ability to "make money", impeccable reputation.

Such understanding of the elite in the minds of the surveyed citizens correlates with the indicators of the answer to the third question, where one should have chosen a picture embodying the elite. Interestingly, almost $20 \%$ of citizens chose a photo as their answer, which implies the criterion of cultural and intellectual development (the second most popular answer after the image with the deputies of the State Duma of the Russian Federation). However, the criteria of closeness and loyalty to the head of state, which the authors largely associate with the "police" state, were overshadowed. Note that respondents were asked to choose the image that best fits the term, rather than the one of the elite they would like to see.

Because of a trial, small empirical study, the authors were interested in the relevance of the Eurasian ideas and their relationship to the Russian reality.

According to the results of the survey, Russian citizens really rely on the fact that the elite, the leading stratum, should be citizens who meet the criteria of representation, law-abiding, high level of spiritual and intellectual development. The question arises as to whether the Eurasian concept of the elite should be implemented or whether some of its features are already included in the recruitment procedure of the ruling stratum.

\section{Discussions}

The results of the study suggest that the Eurasian approach to the concept of the elite, although it has similarities with the Italian concepts of elite V. Pareto and G. Mosca, however, is not devoid of some originality. The historical and comparative aspect of the work shows that Eurasians still relied on the historical experience of selecting the political elite in Russia to formulate special criteria for the selection of the leading stratum.

Despite the development of studies of the elite at the state and regional levels in the post-Soviet space, however, as noted by B. Gelman, I. Tarusina (2000), most of the works are a kind of continuation of the ideas of the classical elite, while the original approaches to the definition of this phenomenon, which would be associated with the peculiarities of the historical development of the state, its economic, spiritual and moral specificity, are still difficult to find.

We believe that a modest attempt to determine the viability of the ideas of the Eurasians at the empirical level, carried out by the authors through the survey, still deserves the attention of representatives of the scientific community and public figures, because, although indirectly, but still indicates that the ideas of the Eurasians in the current stage of development of the Russian state is much closer to understanding for the representatives of the "ruling" society, rather than the ideas of foreign thinkers. 
We believe it is important to note that some sociologists, journalists, and public figures have already attempted to explore the approach to understanding the elite in contemporary Russia among ordinary citizens. Thus, the colta. ru platform conducted a study "Are there any moral authorities in Russia? In our case, it is interesting to note that the top 10 moral authorities in Russia (more than 83,000 people took part in the voting) included people who could not be united in terms of education, popularity, etc. In this sense, representatives of different social groups, professions, age categories of citizens, level of education, nature of activity, etc. were elected as moral leaders, which meets the requirements of "representation".

Also interesting is the research conducted in the early 2000s by Kommersant, in which citizens were asked to choose the President of Russia from among literary characters and film characters. In contrast to these results, a similar study was conducted in 2019 by the Medusa information project, in which heroes of domestic serials became the presumed "ideal" servants of the people (Ten years, 2009).

Meanwhile, the authors have not yet found any scientifically substantiated studies of conservative legal approaches to the interpretation of the elite and their place in the minds of modern Russians. Researchers believe that the scientific work carried out will serve as a starting point for more in-depth study of this issue.

\section{CONCLUSIONS}

The results of the research showed that if we try to define the criteria of the concept of elite in modern Russia, its features, based on historical understanding of the concept, as well as based on the results of the empirical part of the work - the survey, the leading place will be taken by the signs of supra-class representation of the people, a high level of intellectual and spiritual development of members of the elite, the ability to make politically important decisions, managerial experience, moral attitudes. This vision of the elite in general is more similar to the Eurasian approach - the concept of the leading stratum and the ruling selection.

It is clear that the empirical materials collected by the authors of the research are experimental and need to be tested by means of a larger study. In addition, the authors note that they do not have an in-depth knowledge of sociology and admit that the questionnaire needs to be seriously improved, and that the theoretical part of the research can be further developed as part of a longer work on the topic.

Nevertheless, the authors disprove the assumption that the Eurasian concept of ruling selection and leading stratum is just a borrowing, a translation of the already established understanding of the elite, formulated by V. Pareto and G. Mosca. Let us agree that these ideas in some sense are similar and flow from the thoughts of the same philosophers of antiquity and the Middle Ages.

However, if we go deeper into what the named authors understand by the elite, we can see that the Eurasians have managed to make a positive sense of the word in the positive gradation of the elite, proposed by B. Pareto and G. Mosca, to adapt it to the Russian reality, to formulate their own vision of the question. We can easily explain this by the fact that the development of Russian philosophy and science, especially in the conditions of emigration, could not occur in isolation from the world's achievements, including sociology, political science and elite science.

We believe that the results of this research may serve as a basis for a more comprehensive study of this issue. The work may also be useful for comparative analysis of foreign elite and domestic political and legal science, in which the issues of the elite are directly or indirectly affected. 


\section{BIBLIOGRAPHIC REFERENCES}

Alexeev, N.N. (2000). Russian people and state. Moscow. Agraf.

Bassin, M., Glebov, S., Laruelle, M. (2015). Between Europe and Asia: the origins, theories, and legacies of Russian Eurasianism. University of Pittsburg press. 2015.

Chernikov, S.V. (2016). Composition and features of the social status of the secular ruling elite of Russia in the first quarter of the XVIII century. Traditions and innovations, 5, 16.

Gelman, V., Tarusina, I. (2000). Studies of political elites in Russia: issues and alternatives. Communist and Post-Communist Studies, 33, 311-329.

Komissarov, A.V. Problem of political power in the Eurasian heritage. Bulletin of Moscow University, 8(2), 95-98.

Laruelle, . (2015). Eurasia, Eurasianism, Eurasian Union: terminological gaps and overlaps. Ponars Eurasia. Available from: http://www.ponarseurasia.org/node/778/ (Accessed on: 10.08.2019).

Machiavelli, N. (2004). Discourses on the first decade of Titus Livius. Kessinger Publishing, LLC.

Mosca, G. (1939). The ruling class. New York: McGraw Hill.

Palkin, A.G. (2015). The concept of "Ruling Selection" in the ideocratic concept of the Eurasian state. Izvestia Orenburg State Agrarian University, 3(53), 338-339

Pareto, V. (1935). The mind and society. A Treatise on General Sociology. New York: Dower.

Pareto, V. (1968). The rise and fall of the elites: an application of theoretical sociology. New Jersey: The Bedminister Press.

P'erez-Marco, M. (2014). On Pareto theory of circulation of elites. Papers 1412.4695, arXiv.org.

Plato. (2019). The republic. CreateSpace Independent Publishing Platform.

Rachmaninin, A.I. (2007). Social structure of the Old Russian state: IX XIII century. Analyst of culturology, 8, 5-13.

Savitsky, P.N. (1997). Eurasianism as a historical plan. (pp. 98-112). In Continent Eurasia. Moscow. Agraph.

Sergi, B.S. (2018). Putin's and Russian-led Eurasian Economic Union: A hybrid half-economics and half-political "Janus Bifrons". Journal of Eurasian Studies, 9(1), 52-60.

Ten years with Putin. (2009). Kommersant-Vlast, 30, 13.

Three presidential candidates from Russian TV series. Choice of readers of "Medusa". Available from: https:// meduza.io/short/2019/06/05/tri-kandidata-v-prezidenty-iz-rossiyskih-serialov-vybor-chitateley-meduzy/

Trubetskoy, N.S. (2000). Genghis Khan's legacy. Moscow. Agraf.

Vasiliev, A.A. (2016). The concept of conservative stabilisation in Russian society in the 19th-20th centuries. History Questions, 12.

Vorontsov, S.A. (2013). Features of the formation and renewal of elites: history and modernity. Lawyer, 5(60), 4-8. 